\title{
Fostering Educative Experiences in Virtual High School History
}

\section{Rosa Bruno-Jofré}

Queen's University

\section{Karin G. Steiner \\ Steiner International}

\section{ABSTRACT}

This position paper on virtual learning in high school history argues for situating integration of information and communication technologies (ICT) in an ethically defensible vision of education. Our main purpose is to establish a broad theoretical platform to enable critique of new technologies in history classrooms. However, we also argue in favor of embracing ICT integration within a theoretical framework that places teaching and learning as the driving force behind adopting new technologies. First, we remind history teachers in computer-supported classrooms that their teaching is grounded in educational aims and in well-formulated ideas about what constitutes educative experiences. We place the development of the historical mindedness of the student at the core of educational aims in history teaching. Further, it is our contention that high school history modules should become steeped in a vision of education that recognizes its cultural-psychological dimensions. This means dovetailing the construction of content knowledge with teaching the cultural practices of historians and the functions of history.

Key words: technologies of information and communication, history teaching and learning, historical mindedness, cultural psychology, educative experiences

\section{RESUMEN}

Nuestro propósito principal es establecer una plataforma teorética amplia que posibilite la critica de la introducción de nuevas tecnologías en las clases de historia. Argumentamos que es necesario situar la integración de las tecnologías de información y comunicación (TICS) dentro de una vision eticamente defendible de la educación con consiguientes fines educacionales, entendimiento de lo que constituyen experiencias educativas, y el reconocimiento de las dimensiones psicológico-culturales de la enseñanza y el aprendizaje. Esto significa que el proceso debe encuadrar con la enseñanza de las prácticas culturales de los historiadores. Posicionamos el desarrollo de una mentalidad histórica (historical mindedness) en el centro de los fines educativos en la enseñanza de la historia.

Descriptores: technologias de la información y la comunicación, enseñanza y aprendizaje de la historia, mentalidad histórica, psicología cultural, experiencia educative 


\section{RÉSUMÉ}

Notre but principal est d'établir une large base théorique pour la critique des nouvelles technologies dans les classes d'histoire. Dans ce papier nous prenons position pour situer l'intégration de l'informatique dans une vision étiquement défendable de l'éducation et des buts éducationnels reliés, d'idées bien formulées de ce qui constitue les expériences éducatives, et l'identification des dimensions culturelles-psychologiques de l'enseignement et de l'apprentissage. Cette identification signifie agencer la connaissance du contenu avec l'enseignement des pratiques culturelles des historiens et des fonctions de l'histoire. Nous plaçons le développement de la conscience historique de l'étudiant au centre des visées éducatives dans l'enseignement de l'histoire.

Mots-clés: I'informatique (les technologies de l'information et de la communication), l'enseignement et I'apprentissage de l'histoire, la conscience historique, la psychologie culturelle, les expériences éducatives

\section{Background}

$\mathrm{T}$ HERE IS NO DOUBT THAT NEW TECHNOLOGIES have had widespread impact upon a variety of disciplinary areas from the sciences to the humanities (Bereiter, 2002; Schneiderman, 2003). Although most acknowledge the dramatic societal transformation generated by information and communication technologies (ICT), we advocate critique of ICT integration (or use) in history education in the wake of the hegemonic articulation of the concept of an information society (e.g., Apple, 2003). Throughout, we juxtapose critical issues pertaining to ICT integration with a proposal for exploring and evaluating the pedagogical implications of virtual learning in high school history. Our purpose is to develop a broad theoretical framework that links educational theory and cultural psychology to practice.

One underlying assumption here is that pedagogy should drive the adoption of new technologies in high school history classrooms (e.g., Watson, 2001). In particular, we wish to encourage history educators in computer-supported classrooms to ground their teaching in educational aims and in a well-formulated concept of what constitutes educative experiences. We propose historical mindedness (Osborne 2001) as the core educational aim in relation to high school history education. And we argue that historical understanding (e.g., Wineburg, 2000) may be within reach for high school students, given paradigm shifts in teacher preparation, the range of available digital resources, and the possibility of connecting virtually with historians.

However, we doubt that historical mindedness can emerge very readily in the absence of a pedagogy that emanates from practitioner consciousness of the cultural psychological dimensions of learning; namely, the types of activities that reflect or affirm a teacher's philosophy of education, the psychology of student learning, and the dynamics of teaching and learning. Finally, we urge the education community of policymakers, researchers, educators and students to embrace new technologies only after they have first determined how and why these technologies can and should be aligned with pedagogy. 


\section{Linking Virtual Learning with Educational Theory}

There have been positive advances in the use of computing applications in educational research, historical scholarship, and in teaching history. ${ }^{1}$ In Canada, the country most familiar to both authors, ICT integration has played a central role in curriculum development and delivery. There is also a large private for-profit segment in Canada that uses history in various applications, often with instructional or political purposes. Simultaneously, ICT integration has supported the initiation of high school students to the methods of historical inquiry now that high schools have access to online archives and libraries that had previously only been available to scholars or to professional historians. Assorted learning objects (e.g., www.merlot.org/search/ArtifactList.po?catcode=500) have also entered the curriculum so that high school students are now able to explore the process of doing history. In addition, technological developments have permitted a number of multimedia activities (i.e., the downloading and manipulating of audio sources, videos, documents, and 3D learning objects) that have ostensibly enhanced understanding of history as a multi-textual discipline. Further, In Ontario, a number of university researchers in History (in cooperation with teachers) have explored collaborative relationships with technology partners (Bruno-Jofré, Huntley, Stafford \& Moxley, 2004). Researchers have also developed and tested discipline-oriented virtual learning environments (e.g ., www.virtualhistorian.ca), ${ }^{2}$ and history teachers have become active in partnering with governmental agencies such as the Libraries and Archives of Canada and with foundations such as the Historica Foundation (www.histori.ca) to develop ICT teaching and learning initiatives.

What remains underdeveloped at this stage is the critical research called for by the Canadian Association of Deans of Education (LaGrange \& Foulkes, 2004), but also, we argue, what is missing is a sound theoretical and pedagogical framework within which to embrace ICT integration. Our position is that ICT integration efforts in the teaching of high school history require that particular attention be paid to educational aims associated with knowing how to think historically and awareness of the social and political functions of historical knowledge (i.e., historical mindedness). If teaching history involves teaching students to think as historians do (Martineau, 1999) and to understand historical writings by searching for meanings and evaluating claims and presuppositions, then accompanying virtual supports should enhance educational aims. Historical mindedness is understood here following Osborne (2001) as "a way of looking at the world at large that derives from a familiarity with the past and with trying to understand and interpret it" (p. 553). Although Jonassen (2006) argued that software programs can be used as conceptual "mindtools" that serve to develop thinking across the disciplines, we view such technology as subordinate to the "mindwork" 3 of those engaged in teaching and learning history. Further, we contend that teacher preparation programs should encourage prospective teachers of high school history to develop a philosophy of education that encompasses a vision of what constitutes educative experiences, while teachers in the field may need to re-examine their philosophy of education and beliefs about teaching and learning in light of current ICT integration initiatives. 
We suggest that Dewey's sense of "the educative experience" (e.g., Johnston, 2006; Soltis, 1991) provides a logical entry point in support of situating virtual learning within an ethically-defensible vision of education. Specifically, history educators could draw upon Soltis' (1991) interpretation of John Dewey's notion of the educative experience:

An educative experience for an individual is one that grows out of an interest based on purposeful activity and is connected with past and future experiences. It is an experience that helps an individual to transform, reconstruct, and reorganize other experiences. It expands meaning and understanding. It equips us to deal with future experiences more effectively. It stimulates cognitive, emotional, aesthetic, moral and social growth (p. 91).

Our position is that the foregoing concept of the educative experience as linked to the educational aim of developing historical mindedness should be at the forefront in a virtual high school history environment.

\section{Aligning Virtual Learning in History with Cultural Psychology}

In Canada, as Laville (2004) pointed out, historians increasingly lost ground in the history class as the "pedagogy of text" gave way to a "pedagogy of apprenticeship" in historical thinking. This implied a movement from practices that emphasized the interpretations of textbook writers (e.g., historians) to potential focus upon the historical thinking of students. This development converged with positive advances in the use of computing applications in historical scholarship, the teaching of history, and in educational research. ${ }^{4}$ Within this context, cultural psychology (e.g., Cole, 1996; Rogoff, 2003; Tomasello, Kruger \& Ratner, 1993; Vygotsky, 1978) is important to consider in assessing the potential for ICT integration in high school history because it provides a cogent way of understanding how individual thinking is shaped in joint activities with others. Cultural psychology theory provides a way to situate the roles of all educational partners in a teaching-learning dynamic. Further, it permits the educator to reflect upon and build an educational philosophy that is aligned with the individual and collective development of students. This reflective process is based on identifying, examining, and applying beliefs about teaching and learning (e.g., Olson \& Bruner, 1996).

Our analyses suggest that the basic principles for a cultural psychology as outlined by Cole (1996) can inform practices in the teaching of virtual history. Cole defines cultural psychology as a theory of human learning influenced by three types of activity: "psychological processes emerge through culturally mediated, historically developing, practical activity" (p. 108). Cultural mediation by this definition promotes changes in behavior or thinking as a result of manipulating what Cole calls "artifacts" (or tools). In a virtual history classroom such artifacts could be primary sources, archival materials, or other tools that historians use to formulate interpretations of events. Historical development, the second type of activity, refers to a learning process that is achieved in part 
by locating, organizing, and transmitting the store of artifacts of a particular group to succeeding generations. In line with Cole (1996), the teacher in a virtual history classroom, then, would be responsible for directing students to relevant stores of knowledge and to helping them engage with the materials as they begin to build knowledge individually and collectively. The principle of steeping analyses of learning in the everyday activities of humans (i.e., the third type of activity) could also become central to virtual learning in history, provided teachers recognize the utility of drawing attention to the methods and practices of historians, not just to their products. This third type of activity overlaps with the proposed shift away from Laville's (2004) sense of a "pedagogy of text." We are suggesting that a cultural psychological pedagogy could provide the apprenticeship model for students' collaborative knowledge-building, and for conceptual development, hence for rich educative experiences. We also believe that engaging students in culturally mediated, historically developing, practical activity in high school history is likely to foster historical mindedness, or, at the very least, the rudiments of historical literacy.

Research on cognitive and social development also supports applying cultural psychological perspectives to virtual learning in history. For example, Tomasello, Kruger and Ratner (1993) describe the cognitive processes that allow cultural learning to proceed and they discuss the biology of such processes using a comparative psychology approach. These researchers outline a sequence of learning from imitative learning to instructed learning to collaborative learning, each of which involves increasingly complex levels of perspective-taking. Further, Barbara Rogoff $(1990,2003)$ offers a cogent overview of the role of social interaction in both spurring and advancing cognitive development. The underlying principles of guided participation as described in Apprenticeship in Thinking and in The Cultural Nature of Human Development could be applied to students engaged in a computer-supported history classroom. Rogoff (1990) explains:

Guided participation involves collaborative and shared understanding in routine problem-solving activities. Interaction with other people assists children in their development by guiding their participation in relevant activities, helping them adapt their understanding to new situations, structuring their problemsolving attempts, and assisting them in assuming responsibility for managing problem-solving. This guidance of development includes tacit and intuitive forms of communication and distal arrangements of children's learning environments....(p 191).

The cultural practice of guided participation involves a teacher's understanding of cognitive development, of disciplinary knowledge, and the teacher's beliefs about students, how they learn disciplinary knowledge, and beliefs about the role of the teacher in knowledge production. Thus, we argue that teacher education programs should also require prospective practitioners to link an understanding of cultural learning processes to their own developing philosophy of education. To that end, David Olson and Jerome Bruner (1996) provide examples that support aligning folk psychologies cen- 
tered on beliefs about how people think and learn with folk pedagogies that encompass the role of the teacher, that of students, and beliefs about the role of the teacher.

In keeping with the foregoing, we suggest that particular attention be paid to the design of a virtual history environment and to the activities it permits such that facets of ICT integration (either embedded in the information technology itself or in the practices associated with their use) make explicit educational aims and beliefs about teaching and learning. In making such underlying assumptions about the educational process explicit, a teacher and the teaching environment enable and shape the educative experience of individuals and the group. Further, we suggest that such conditions are likely to promote knowledge-building, and a deeper understanding of the role of the community of scholars. While some researchers are applying activity theory (a branch of cultural psychology) in studying computer-supported collaborative learning in science classrooms (e.g., van Aalst \& Hill, 2006), others remain focused on individual learning in the context of developing understanding in a discipline (i.e., with levels ranging from "naïve-" to "novice-" to "apprentice-" to "master understanding"). Some of this latter work has been applied in history (e.g., Hetland, Hammerness, Unger \& Wilson, 1998). Other researchers suggest turning towards videogames to stimulate constructivist curricula via simulations that engage participants in disciplinary problem solving (Squire, 2006). Adapting such models to integrate both collective and individual approaches should be considered in designing virtual history environments that strive to promote historical mindedness.

Other researchers interested in cross-disciplinary ICT integration have argued from a socio-cultural perspective that "collective and critical discussion supports students to enter the 'inner world' of a school subject" (Sutherland et al., 2004, p. 419). We agree, but our position is that entering the 'inner world' of history will entail developing historical mindedness, and that this state of mind is enhanced through awareness of the socio-cultural practices of historians. Sutherland et al.'s (2004) study of ICT integration in six subject areas (including high school history) found that new technologies worked best in classrooms where the teacher viewed the technology as a mediating cultural tool. And successful ICT integration in Sutherland et al.'s InterActive Education Project was related to the extent to which teachers found "mechanisms for students to present their work for critical feedback from others as a way of shifting emphasis from individual knowledge to collective and shared knowledge" (p. 419). Given the evidence from specialist studies, our position is that cultural psychological approaches provide a promising complement to educational theory in considering the educational aims, educative experiences, and the potential to develop historical mindedness in virtual high school history classrooms.

\section{The Role of the Teacher in Shaping Educative Experiences}

The role of the teacher is central to shaping the educative experiences of students in high school history, though teachers and students can become education partners or joint "users" in a virtual environment. However, because teachers have more discipli- 
nary knowledge than their students, they are in a prime position to guide student learning based on knowledge of the students and of the target discipline. The teacher can also be viewed as a mediator between communities of students and communities of experts by being a participant in both (Gregory, 2002; Seixas, 1993). ${ }^{5}$ This position squares with the concept of a more skilled adult guiding the apprenticeship in thinking of the student (Rogoff, 2003) and with the concept of a dynamic developmental state between a learner and his or her more knowledgeable partner as they work within a zone of proximal development (Vygotsky, 1978).

Therefore, we suggest that teacher preparation programs in which ICT initiatives are introduced also accompany ICT initiatives with teaching in educational theory and in concepts of cultural learning. At the core of such programming would be opportunities to build awareness of one's developing philosophy of education, and of how to examine beliefs about teaching and learning. Olson and Bruner (1996) show how the concept of learner as doer, knower, thinker, or expert can in turn parallel the role of teacher as demonstrator, expositor, collaborator, or information manager. Accordingly, within these same four parallel levels, a student can be viewed as one who imitates, comprehends, interprets, or as one who constructs knowledge, whereas a teacher can be conceived of as craftsperson, authority, colleague, or as consultant. The process of teaching and learning history can parallel those roles when articulating the acquisition of historical knowledge (substantive) to the understanding of the procedures and standards of the discipline (skills) and also when understanding an author's (historian's) formulation of argument and use of evidence. Students should know something about the grounds for various kinds of claims made by historians without necessarily becoming "miniature professional historians" (Lee \& Ashby, 2000, p. 200). A challenging example could be the way the students understand themselves as historical beings. ${ }^{6} \mathrm{We}$ suggest that such understanding could provide a foundation for the student's developing sense of historical mindedness.

As pre-service teachers become conscious of their pre-existing beliefs, they may become more open to adopting different roles and different beliefs about teaching and learning. We contend that pre-service teachers will think more deeply about what constitutes an educative experience if they understand how folk psychologies align with folk pedagogies. It is unlikely that simple appeals to pre-service teachers to adopt, say, a constructivist approach to designing virtual learning experiences (e.g., Jonassen, 1996) will influence their practice profoundly. By the same token, the teacher's familiarity with history debates and with the state of the discipline may help mediate an educative inquiry process that would lead to growth in terms of the building of robust meanings and satisfying experiences (Johnston, 2006, p. 196). ${ }^{7}$

\section{Historical Mindedness as an Ultimate Goal in Teaching History}

Educative experiences demand high levels of understanding amongst all learning partners (i.e., amongst teachers, individual students and their peers, and a broader scholarly community). Such understanding has been characterized as integrative, critical, and 
creative (Boix Mansilla \& Gardner 1998). In a similar vein, the process of learning how to think historically and understanding history can be linked to thinking like an historian (to interpreting, synthesizing, and weighing evidence from primary sources) and to assessing claims in a historiographical text. In addition, an educative experience should be worthwhile, lead to the desire for new understandings, and, as Dewey said, it should be transformative.

However, the foregoing points are particularly relevant to the teaching of high school history, given its links to the citizenship and identity formation debate and to the discussion on the political and societal functions of historical knowledge. The use of ICT in the classroom or in a networked collaborative virtual environment may open new ways of thinking about collaborative scholarship, sharing of information, and it may also create new public spaces that lead to different forms of civil engagement. At this juncture, we wish to remind the education community that it will need educational research to examine these possibilities if ICT integration is to be recognized empirically and granted credibility as an important educational tool.

Stéphane Levesque (2005) argues that "the digital history revolution has, intentionally or not, rendered history more friendly and communicative"; the promise is that students are now enabled to enter into collaborations with historians and teachers in other locations based on their particular lines of inquiry (see H-Net at www.h.net.org). However, we are arguing here that such promises of the digital revolution cannot be fulfilled in a theoretical vacuum. We claim that to have a meaningful democratic learning environment and to develop a sustainable civil society, the integration of ICT should be rooted in an ethically defensible vision of education that fosters a historicallyminded worldview (Bruno-Jofré, 2002).

Historical-mindedness defined as a disposition and an outlook deriving from the development of the skills and attitudes related to historical thinking implies qualities that are desirable in a literate and democratically-minded person. Some of those dispositions are: detachment from immediate pressures; an ability to search for comparisons; readiness to subject emotions to reason; a sense of understanding that there is more than one perspective and that issues are such because there is more than one conception of what is right or necessary; the ability to weigh forces of change and continuity; and, an awareness that institutions and values can change over time (Osborne, p. 53). ${ }^{8}$ In fact, even though a more friendly and communicative technological face for high school history instruction marks a positive advance, students may not be able to realize the potential for establishing networks or communities of inquiry without historical understanding or without knowing how to set out the warrants, support provisional accounts advanced, and justify the judgments those accounts entail. The role of the teacher as a mediator is relevant in this context. Further, we argue that prospective teachers should be apprised of the way(s) that virtual tools could advance the cultural learning process in history.

Bereiter and Scardamalia (2006) conceptualized the shifts in ICT integration movements in school as waves. The initial wave involved simply acknowledging a need to insert new technologies in classrooms; the next wave focused on the use of these new technologies; but the third wave - which has not yet been fully realized - is the notion 
of technology as an "affordance" that can promote optimal social dynamics, so that students become part of a community of inquirers and so that they become knowledge constructors. It is in this latest possible wave of ICT integration that awareness of cultural psychology becomes particularly salient, especially in terms of how the social processes involved in learning contribute to the development of the individual and to the community of inquirers. However, the virtual learning environment on its own, as we discovered in the e-heritage virtual globe project (Bruno-Jofré \& Steiner, 2005), does not necessarily stimulate third wave types of activity, which in history teaching would mean stimulating historical understanding and knowledge co-construction amongst a community of inquirers. ${ }^{9}$ The students in this class seemed more intrigued by the technology itself than by the conceptual leaps the advanced ICT might have afforded them. Thus, this class could have been characterized as a "first wave" class in Bereiter's and Scardamalia's (2006) sense of the term.

\section{Challenges to the Teaching of History in a Virtual Environment}

The main challenge to virtual learning in high school history involves developing a pedagogy that is informed by educational theory and cultural psychological practices. What has been missing to date from technological advances is an accompanying conceptual framework beyond the lesson plan and its objectives, one that harnesses explicit educational aims and cultural psychological foundations of learning to promote educative experiences and disciplinary knowledge-building. We suggest placing considerable effort upon developing a research base from which to examine local practices in virtual environments. To date, very little such work exists, apart from some primarily UK-based studies (e.g., Galanouli \& McNair, 2001; Haydn \& Counsell, 2003; Sutherland et al., 2004; Taylor, 2003; Tolmie, 2001; Watson, 2001). We suggest that research designs should include naturalistic studies of virtual learning environments. In such a research paradigm, teachers could be viewed as central mediators between schools and the community of historians, and students could be seen as knowledge constructors. Thus, the virtual history classroom could be construed as a particular context for cultural learning, one that takes into account the perspectives of all educational partners. Further, the study of virtual learning in high school history classroom practices could also be linked to wider spheres of education, ones that encompass teacher education programs and the impact of ICT integration on learning disciplinary knowledge in history.

In addition to the need to apply suitable theoretical perspectives to improve pedagogy in virtual history classrooms, there are also pending technological issues that remain to be resolved. These pose challenges to teaching and learning in a virtual environment. Teachers and researchers alike have encountered design and interface problems that create delays and frustration and that underline the need for predictable and controllable interfaces (Schneiderman, 2003). Of equal import is the problem of the instability generated by vendors who promote a proliferation of new versions of programs that satisfy market rather than consumer priorities. This instability can serve to bias educators against previewing or investing learning time in new products. 
While a number of educators are eager to explore new frontiers, the usability of new products may be undercut or inadvertently impeded by developers who behave like artists in creating exciting programs that are too complex to navigate for those who are novices. Further, Watson (2001) has outlined another set of serious problems emanating from: “...continuing emphasis on using applications that were designed for business rather than for learning, an emphasis on information rather than knowledge, and a policy focus on technology as workforce training” (p. 262). Moreover, we cannot forget that students in the information age are immersed in new technologies in their home life. This means that idiosyncratic or informal use of new technologies probably affect formal uses of ICT at school (Sutherland et al., 2004).

Given the foregoing issues, the university, its educational researchers, and its technology partners have a role to play in providing access to new technologies, so that pre-service teachers and teachers in the field have the opportunity to examine and critique ICT tools. Researchers in the UK found that pre-service teachers who were wellversed in ICT integration were faced with barriers to implementing ICT-supported strategies in practicum placements with teachers who had not found ways to apply new technologies (Galanouli \& McNair, 2001). The implication is that universities should support pre-service teachers in ICT integration, but also, that they should provide professional development opportunities for associate teachers in the field who are mentoring teacher candidates.

Failure to provide an avenue for exploring the potential (and possible pitfalls) of new technologies prior to adopting them in schools means that ICT integration could continue to be viewed as a problem, or, in Sutherland et al.'s (2004) words as a kind of Trojan Horse, "secretly bringing in new approaches to learning that [conflict] with the deep grammar of [a] subject" (p. 417). These researchers have linked the success or lack of success of ICT integration to teacher beliefs about new technologies. Others remind us that teachers are at the forefront of change in schools in general (e.g., Watson, 2001). Thus, universities involved in teacher preparation and their technology partners would do well to find ways to evaluate new technologies in field studies that explore teaching and learning dynamics in natural settings. In this way, possible clashes between informal and formal learning practices, between teacher beliefs and technology applications, or between teacher candidates with expertise in ICT integration and associate teachers who have reservations about new technologies could be resolved.

\section{Conclusion}

The technological revolution is transforming the very tenets of education as a profession which Faculties of Education intellectually sustain. In this paper we outlined ways that the "mindtools" of the virtual environment become pedagogically meaningful when they are subordinated to the "mindwork" involved in the process of developing historical mindedness. And we encouraged practitioners interested in virtual history to frame their pedagogy in an ethically-defensible vision of education. We suggested a broad theoretical platform that integrates educational aims, a concept of what consti- 
tutes educative experiences, and the introduction of cultural psychological approaches along with new technology applications. We indicated that the history teacher must have foundational views, but also knowledge of how students learn collectively, and how pedagogy promotes disciplinary understanding of history. Throughout, we proposed historical-mindedness as the keystone educational aim in relation to history education because, we believe, developing historical understanding provides a promising avenue for building a literate and critical citizenry.

\section{Notes}

1 See McMichael, Rosenzweig \& O’Malley (1996); Thomas (2001, 2003); and, the National Endownment for the Humanities EdSitement list at http://edsitement.neb.gov/

2 The Virtual Historian is a web-based educational program for teaching Canadian history in both official languages. It has been developed by a team of scholars from the Althouse Faculty of Education at the University of Western Ontario under the leadership of Stéphane Levesque. The Virtual Historian places students in the virtual environment of authentic historical investigations of key events and issues in Canadian History, such as the Halifax Explosion (1917), the Dieppe Raid (1942), and the October Crisis (1970).

3 We define "mindwork" in high school history as students' interpretations of source materials and their consequent construction of evidence-based arguments that have been discussed, evaluated, or critiqued.

4 SeeMcMichael, Rosenzweig \& O’Malley (1996); Thomas (2001,2003); and, the National Endownment for the Humanities EdSitement list at http://edsitement.neb.gov/

5 However, autonomous self-correction and self-verification central to constructivist pedagogy are approached by Gregory $(2002,397)$ in relation to the need to "reconcile the pragmatist defense of 'warrantability' (against, for instance, relativism with the credo of fallibilism). In this line of thought, we concur with the idea that teachers have authoritative knowledge and that this knowledge is privileged over that of students.

6 See Wineburg (2000, chapter 10). In 1996, with the help of a grant from the Spencer Foundation, the author did a study of how ordinary people conceptualize their lives as historical beings by following the lives of 15 adolescents from three different high schools from Seattle. Wineburg explores empirically the difference between living memories and learned memories and "the colliding worlds of history and memory".

7 Johnston (2006) understands inquiry as context-based and self-correcting. However, he qualifies that by saying that "it requires at a minimum those technologies and facilities necessary to carry out the intended direction of the student's experience" (p. 196-197). In relation to the reflective practitioner and the teaching and learning of history, see Drake and Nelson (2005, p. 207).

8 Osborne (2001) points out these dispositions which characterize historical-mindedness; he took the concept and characterization from a report produced by the American Historical Association's Committee of Seven in 1899. Osborne does not construe historical-mindedness as an aim as we do here. Instead, he introduces the concept as an alternative to thinking historically or thinking like historians. Osborne also recommends that we investigate how the study of history affects the students' worldview and their understanding of what it means to be human.

9 This virtual globe (VG) was developed by GRIDS and the Kingston Software Factory in Ontario, Canada. Its special platform was designed for P2P connectivity, and it supports rapid, accurate and repeatable access and display for multiple concurrent datasets. The VG is based on a mathematics that supports rapid, regular decomposition, i.e., SEA3H Discrete Global Grid (Bruno-Jofré et al., 2004). 


\section{References}

Apple, M. (2003). Is the new technology part of the solution or part of the problem in education? In A. Darder, M. Baltodano \& R. D. Torres (Eds.), The critical pedagogy reader, pp. 440-458. New York and London: Routledge Falmer.

Bereiter, C. (2002). Education and mind in the knowledge age. Mahwah, NJ and London, UK: Lawrence Erlbaum.

Bereiter, C., \& Scardamalia, M. (2006) Information and communication technology: Catching the third ICT wave. Queen's University Education Letter (Spring-Summer): Integrating ICT in teaching and learning, pp. 1-3.

Boix Mansilla, V., \& Gardner, H. (1998). What are the qualities of understanding? In M. S. Wiske (Ed.), Teaching for understanding (pp. 161-196). San Francisco: Jossey-Bass.

Bruno-Jofré, R., Huntley, F., Stafford, J., \& Moxley, J. (2004). Exploring our world: A journey through space: Developing an inquiry model for the teaching of history through the virtual globe. Presentation at Global Forum 2004: Shaping the Future: The Broad Convergence. Malmo (Sweden). ITEMS International, www.Items-int.com.

Bruno-Jofré, R. (2002). Should developments in information technology be informed by educational aims? Presentation at Global Forum 2002. Shaping the Future: A World in Transition: The Promise of Broadband Services, Towards the Multimedia and Knowledge Society. George Washington University, ITEMS International (France), Foundation Sophia Antipolis, www.items-int.com.

Bruno-Jofré, R., \& Schiralli, M. (2002). Teaching history: A discussion of contemporary challenges. Encounters on Education, 3, 117-127.

Bruno-Jofré, R., \& Steiner, K. (2005). The e-Heritage virtual globe: From conceptual framework to field test of a trial module. Report submitted to the Kingston Software Factory, in fulfillment of a contract to complete a pilot project with funding from the Canadian pace Agency.

Cole, M. (1996). Cultural psychology: A once and future discipline. Cambridge, MA: Belknap Press of Harvard University Press.

Drake, F., \& Nelson, L. (2005). Engagement in teaching history: Theory and practices for middle and secondary teachers. Columbus, $\mathrm{OH}$ : Pearson, Merrill Prentice Hall.

Fay, B. (1998). Introduction: The linguistic turn and beyond in contemporary theory of history. In F. Fay, P. Pomper \& R. T. Vann (Eds.), History and theory: Contemporary readings (pp. 1-12). Malden, MA: Blackwell.

Galanouli, D., \& McNair, V. (2001). Students' perceptions of ICT-related support in teaching placements. Journal of Computer Assisted Learning, 17, 396-408.

Gregory, M.R. (2002). Constructivism, standards, and the classroom community of inquiry. Educational Theory, 52(4), 397-408.

Haydn, T., \& Counsell, C. (2003). History, ICT and learning in the secondary school. London, UK: Routledge/Farmer.

Hetland, L., Hammerness, K., Unger, C., \& Wilson, D. G. (1998). How do students demonstrate understanding? In M. S. Wiske (Ed.), Teaching for understanding (pp. 197-232). San Francisco: Jossey-Bass.

Johnston, S. J. (2006). Inquiry and education: John Dewey and the quest for democracy. Albany NY: State University of New York Press.

Jonassen, D. (2006). Learning with technology: Not from it. Invited MSTE-Royal Bank Lecture, Faculty of Education, Queen's University, Kingston, Ontario, Canada.

Jonassen, D. (2003). Using cognitive tools to represent problems. Journal of Research on Technology in Education, 35(3), 362-381.

Jonassen, D. (1996). Thinking technology: Toward a constructivist design model. Educational Technology, 34(4), 34-37. 
LaGrange A., \& Foulkes, E. (2004) Emergent framework for ICT integration within Faculties of Education. Summary of the report prepared for Industry Canada on behalf of the Canadian Association of Deans of Education.

Laville, C. (2004). Historical consciousness and historical education: What to expect from the first for the second. In P. Seixas (Ed.), Theorizing historical consciousness (pp.165-182). Toronto-Buffalo-London: University of Toronto Press.

Lee, P., \& Ashby, R. (2000). Progression in historical understanding among students ages 7-14. In P. N. Stearns, P. Seixas \& Wineburg, S. (Eds), Knowing, teaching and learning history (pp.199-222). New York and London: New York University Press.

Levesque, S. (2005). (Un)covering the past: Engaging Canadian students in virtual history. Keynote address to the symposium "History Alive! Old Sources, New Technology" hosted by the Teaching of History Research Group, Queen's University, Kingston, ON.

Martineau, R. (1999) L'histoire á l'école: Matière à penser. Paris, France: L'Harmattan.

McMichael, A., Rosenzweig, R., \& O' Malley, M. (1996). Historians and the web: A beginner's guide. The American Historical Association, Perspectives, January. http://www.historians.org/perspectives/issues/1996/9601/9601COM3.CFM, accessed 21 July 2006.

MERLOT www.merlot.org/search/ArtifactList.po?catcode=500)

National Endownment for the Humanities EdSitement list at http://edsitement.neb.gov/

Olson, D. R., \& Bruner, J. S. (1996) Folk psychology and folk pedagogy. In D. R. Olson \& N. Torrance (Eds.), Handbook of education and human development (pp. 9-27). Malden, MA: Blackwell.

Osborne, K. (2001) Review of the books "Knowing, teaching and learning history. Edited by P. Stearns, P.Seixas, and S. Weinburg (2000) New York University Press and "L'histoire à l' école: Matière à penser. Robert Martineau (1999) Paris/Montreal: L' Harmattan. In The Canadian Historical Review, 82(3), 548-555.

Priegert-Coulter, R. (2003). Why we teach history: A contesting view (Invited Introduction). Encounters/Encuentros/Rencontes on Education, 3,1-5.

Rogoff, B. (1990). Apprenticeship in thinking: Cognitive development in social context. New York: Oxford University Press.

Rogoff, B. (2003). The cultural nature of human development. New York: Oxford University Press.

Schneiderman, B. (2003). Leonard's laptop: Human needs and the new computing technologies. Cambridge, MA and London, UK: The MIT Press.

Seixas, P. (1993). The community of inquiry as a basis for knowledge and learning: The case of History. American Educational Research Journal 30 (2), 305-324.

Soltis, J. (1991). Humanizing education: Dewey's concepts of a democratic society and purpose in education revisited. Studies in Philosophy and Education 11, 89-92.

Squire, K. (2006). From content to context: Videogames as designed experience. Educational Researcher, 35(8), 19-29.

Sutherland, R., Armstrong, V., Barnes, S., Brawn, R., Breeze, N., Gall, M., Matthewman, S., Olivero, F., Taylor, A., Triggs, P., Wishart, J., \& John, P. (2004). Transforming teaching and learning: Embedding ICT into everday classroom practices. Journal of Computer Assisted Learning, 20, 413-425.

Taylor, L. (2003). ICT skills learning strategies and histories of trainee teachers. Journal of Computer Assisted Learning, 19, 129-140.

Thomas, W. G. III (2001). Blazing trails toward digital history scholarship. Histoire Sociale/Social History, XXXIV (68):415-426.

Thomas, W. G. III \& Ayers, E. L. (2003). An overview: The differences slavery made: A close analysis of two American of Two American Communities. The American Historical Review 108(5): 20 pars. 21 Jul. 2006 <http://www.historycooperative.org/journals/ahr/108.5/ thomas.html>. 
Tolmie, A. (2001). Examining learning in relation to the contexts of use of ICT. Journal of Computer Assisted Learning, 17, 235-241.

Tomasello, M., Kruger, A. C., \& Ratner, H. H. (1993). Cultural learning. Behavioral and Brain Sciences, 16, 495-552.

Van Aalst, J., \& Hill, C. M. (2006). Activity theory as a framework for analyzin knowledge building. Learning Environments Research, 9, 23-44.

Vygotsky, L. S. (1978). Mind in society: The development of higher psychological processes. Edited by M. Cole, V. John-Steiner, S. Scribner \& E. Souberman. Cambridge, MA: Harvard University Press.

Watson, D. M. (2001). Pedagogy before technology: Re-thinking the relationship between ICT and teaching. Education and Information Technologies, 6(4), 251-266.

Wineburg, S. (2000) Historical thinking and other unnatural acts: Charting the future of teaching the past. Philadelphia, Temple University Press.

www.histori.ca [Retrieved 25 July 2006]

www.virtualhistorian.ca [Retrieved 25 July 2006]

Yacci, M., Haake, A., \& Rozanski, E. (2004) Operations and strategy learning in edutainment interfaces. Paper presented at AACE World Conference on Educational multimedia, hypermedia, and telecommunications. Lugano, Switzerland. 2004.

\section{Acknowledgements}

We are grateful to The Kingston Software Factory and to Joe Stafford for help in developing a pilot project at the Faculty of Education at Queen's University, Canada, so that high school history students could be exposed to an instructional module using GRID's Virtual Globe. A version of this paper was presented at the American Educational Research Association conference in Chicago in April, 2007. A Spanish translation of a longer version of this paper appears in Teoría de la Educación: Educacion y Cultura en la Sociedad de la Informacion, vol. 8, No. 4 (http://www.usal.es/-teoriaeducacion). 